\title{
Estimation of genetic parameters and genotype effects for crossing constructions of Hungarian Pigs
}

\author{
Henrietta Nagyné Kiszlinger - Marcell Molnár - István Nagy \\ University of Kaposvár, Faculty of Animal Science, Kaposvár \\ kiszlinger.henrietta@ke.hu
}

\section{SUMMARY}

\begin{abstract}
Authors estimated the genetic parameters and genotype effects of average daily gain (ADG), age (AGE) and lean meat percentage (LMP) using the field test data of Pietrain (Pi), Duroc (Du), Hampshire (Ha) pigs and their crosses. Data was collected by the Agricultural Agency of Administration between 1998 and 2010 originating from 68 herds. Datasets of the different crossing combinations (Pi, Du, Pi $\times D u ; P i, H a$ $P i \times H a)$ were evaluated separately using bivariate animal models. The estimated heritabilities were moderately low: 0.24-0.29, 0.22-0.26 and 0.18-0.19 for average daily gain $(A D G)$, age $(A G E)$ and lean meat percentage (LMP), respectively. The estimated genetic correlation coefficients were negligible: -0.07-0.01 (ADG-LMP), -0.01-0.04 (AGE-LMP). The Pi $\times$ Ha and $P i \times D u$ crosses showed $6.76 \%$ and $4.96 \%$; $6.74 \%$ and $4,17 \%$ and $0.08 \%$ and $0.44 \%$ heterosis for $A D G, A G E$ and $L M P$, respectively. Among the environmental factors the herd effects were substantial: $41.17 \%, 53.67 \%$ and $14.16 \%$ for $A G D, A G E$ and $L M P$, respectively. The smallest environmental influences were found for LMP.
\end{abstract}

Keywords: swine, genetic parameters, average daily gain, age, lean meat percentage

\section{ÖSSZEFOGLALÁS}

\begin{abstract}
A szerzök az átlagos napi tömeggyarapodás (ADG), az életnap (AGE) és a szinhús százalék (LMP) genetikai paramétereit és a genotipus hatást vizsgálták pietrain (Pi), duroc (Du), hampshire (Ha) és a keresztezett genotípusok ÜSTV adatai alapján. Az adatokat az MgSZH 1998 és 2010 között 68 telepröl gyüjtötte. A különbözö keresztezési kombinációk (Pi, Du, Pi × Du; Pi, Ha Pi × Ha) adatbázisát külön értékeltük kétváltozós egyedmodell alkalmazásával. A becsült öröklödhetöségeket mérsékleten alacsonynak találtuk: 0,24-0,29; 0,22-0,26 és 0,18-0,19 az átlagos napi tömeggyarapodásra (ADG), az életnapra (AGE) illetve a színhús százalékra (LMP). Elenyészö genetikai korrelációkat becsültünk a vizsgált tulajdonságok között: -0,07-0,01 (ADG-LMP), -0,01-0,04 (AGE-LMP). A Pi × Ha és a Pi × Du keresztezett genotípusok 6,76\% és 4,96\%; 6,74\% és 4,17\%; 0,08\% és 0,44\% heterózist mutattak az ADG, AGE és az LMP tulajdonságokban. A környezeti hatások közül a telep hatása kiemelkedö volt: 41,17\%, 53,67\% és 14,16\% az AGD, AGE illetve az LMP tulajdonságokban. A legkisebb környezeti hatást az LMP tulajdonságban becsültük.
\end{abstract}

Kulcsszavak: sertés, genetikai paraméterek, átlagos napi tömeggyarapodás, életnap, szinhús százalék

\section{INTRODUCTION}

During the last two decades the BLUP breeding value estimation became a wide-spread procedure in every animal breeding sector. The Hungarian pig breeding sector was no exception and after an extremely long transition period (more than 10 years) the BLUP procedure became official in 2009 (MGSZH, 2009). Since then the genetic merit of the Hungarian pig populations are obtained by means of BLUP evaluations that are based on the various performance test data (field and station tests). Generally the BLUP procedure was developed for purebred animals. An overview about the application of BLUP in the various breeding programs and about the various BLUP models was given by Komlósi (1999) and Szőke and Komlósi (2000). However applying crossing is one of the main characteristics of the pig breeding sector. In order to evaluate crossbreds one possibility is to use pooled datasets and pedigrees of all genotypes participating in a given cross. Although the genetic parameters of the Hungarian purebred pig populations were reported by several studies (Csató et al., 2002; Csató et al., 2004; Farkas, 2008; Nagy et al., 2009) no relevant literature is available about the genetic parameters of crossbreds or about the estimated genotype effects describing the efficiency of the different crosses. These were the objectives of this study.

\section{MATERIALS AND METHODS}

Analyses were based on the field test data of Pietrain (Pi, 5717), Duroc (Du, 4868), Hampshire (Ha, $1157)$ pigs and their crosses $(\mathrm{Pi} \times \mathrm{Ha}, 8210, \mathrm{Pi} \times \mathrm{Du}$, 4728). Data was collected by the Agricultural Agency of Administration between 1998 and 2010 from 68 herds. Total number of animals in the pedigree files were $60926(\mathrm{Pi}, \mathrm{Du}, \mathrm{Pi} \times \mathrm{Du})$ and $42004(\mathrm{Pi}, \mathrm{Ha}, \mathrm{Pi} \times \mathrm{Ha})$, respectively. In the field test ultrasonic (SONOMARK 100) fat depth measurements were taken from boars and gilts between 80 and $110 \mathrm{~kg}$ between the $3^{\text {rd }}$ and 4 th lumbar vertebrae $(8 \mathrm{~cm}$ laterally from the spinal cord), between the $3^{\text {rd }}$ and $4^{\text {th }}$ ribs $(6 \mathrm{~cm}$ laterally from the spinal cord) and the loin muscle area between the $3^{\text {rd }}$ and $4^{\text {th }}$ ribs $(6 \mathrm{~cm}$ laterally from the spinal cord). Using these measurements lean meat percentage (LMP) can be calculated. This trait was used officially in the field test only from 2000 (MGSZH, 2000) but it was collected from 1998. (Age (AGE) and body weight (with an accuracy of $1 \mathrm{~kg}$ ) of the animals were recorded at the same time from which their average daily gain (ADG) was also calculated. In order to have balanced data structure only those records were used where the animals had measurements for all traits. The regulations of animal housing and feeding conditions are defined in the Hungarian Pig Performance Testing Code (MGSZH, 2009). Descriptive statistics were 
calculated using SAS 9.1 (SAS Inst. Inc., Cary, NC). Genetic parameters of ADG, AGE and LMP were estimated by the REML method using bivariate animal models applying VCE6 (Groeneveld et al., 2008). The magnitude of the genotype effects were estimated by BLUP (using the PEST software) (Groeneveld, 1990) with the same model mentioned previously.

The structure of the applied animal model was the following:

$$
\mathrm{y}=\mathrm{Xb}+\mathrm{Za}+\mathrm{Wc}+\mathrm{e}
$$

$y=$ vector of observations, $b=$ vector of fixed effects, $\mathrm{a}=$ vector of random animal effects, $\mathrm{c}=$ vector of common litter effect, $\mathrm{e}=$ vector of random residual effects, $\mathrm{X}, \mathrm{Z}$ and $\mathrm{W}$ are incidence matrices relating records to fixed, random animal and common litter effects, respectively.

In the model year-month, sex, herd effects were treated as fixed effects, while additive genetic and common litter effects were considered as random effects.

\section{RESULTS AND DISCUSSION}

Descriptive statistics of the examined traits are provided in table 1 for each genotype. The Pietrain pigs showed the highest LMP values which finding was in accordance with the literature (Geysen et al., 2000; Youssao et al., 2002; Klimas and Klimiené, 2009). On the contrary the ADG and AGE of the Pietrain pigs were lower and higher than that of Hampshire and Duroc pigs. Similar results were reported by Jasek et al. (2006) although they found larger differences between the Hampshire and Duroc pigs to the advantage of the latter breed. Wolf et al. (2006) however, reported lower ADG for Ha compared to Pietrain pigs.

Table 1.

Descriptive statistics of the examined traits

\begin{tabular}{lcrrrrr}
\hline \multicolumn{1}{c}{ Trait } & Genotype & \multicolumn{4}{c}{ N } & \multicolumn{1}{c}{ Minimum } \\
\hline LMP & Pi & 5717 & 52.70 & 68.00 & 61.72 & 2.10 \\
ADG & & 5717 & 283.00 & 774.00 & 526.61 & 60.51 \\
AGE & & 5717 & 120.00 & 295.00 & 176.15 & 23.18 \\
LMP & Du & 4868 & 50.00 & 66.80 & 58.22 & 1.87 \\
ADG & & 4868 & 318.00 & 756.00 & 557.02 & 56.61 \\
AGE & & 4868 & 120.00 & 285.00 & 174.80 & 21.75 \\
LMP & Pi $\times$ Du & 4728 & 52.50 & 66.00 & 59.74 & 2.02 \\
ADG & & 4728 & 317.00 & 764.00 & 565.98 & 67.93 \\
AGE & & 4728 & 120.00 & 282.00 & 168.45 & 21.60 \\
LMP & Ha & 1157 & 54.00 & 65.00 & 59.46 & 1.79 \\
ADG & & 1157 & 361.00 & 809.00 & 560.08 & 80.56 \\
AGE & 1157 & 120.00 & 281.00 & 172.75 & 25.74 \\
LMP & Pi $\times$ Ha & 8210 & 54.00 & 65.00 & 60.93 & 1.38 \\
ADG & & 8210 & 346.00 & 846.00 & 576.27 & 65.72 \\
AGE & 8210 & 120.00 & 280.00 & 162.00 & 18.50 \\
\hline
\end{tabular}

Source: own edition

The estimated heritabilities of the examined traits were moderately low based on both datasets $(\mathrm{Pi}, \mathrm{Du}$, $\mathrm{Pi} \times \mathrm{Du}$; $\mathrm{Pi}, \mathrm{Ha} \mathrm{Pi} \times \mathrm{Ha}$ ) (table 2$)$. Our results were in agreement with the findings of other studies (Lo et al., 1992; Serbán et al., 2000; Bühler and Postler, 2004; Nagy et al., 2008; Radnóczi et al., 2009). Other authors reported larger heritability estimates $(0.40-0.64)$ for LMP (Knapp et al., 1997; Bühler and Postler 2004; Kanis et al., 2005; Stamer et al., 2007, 2008) or for ADG (0.34-0.39) (Váradi et al., 1997). For ADG Váradi et al. (1997) did not use animal models which can be the reason of the higher estimates. However the high heritability estimates of the above mentioned authors were obtained by means of animal models which may suggest of the possibility of imprecise ultrasound scanning for our dataset. As Kövér et al. (2002) demonstrated the LMP estimation using ultrasound scanning on live animals is relatively imprecise compared to other procedures.

Table 2.

Heritability estimates of the examined traits (standard errors are given in brackets)

\begin{tabular}{lcc}
\hline & $\mathrm{Pi}, \mathrm{Ha}, \mathrm{Pi} \times \mathrm{Ha}$ & $\mathrm{Pi}, \mathrm{Du}, \mathrm{Pi} \times \mathrm{Du}$ \\
\hline ADG & $0.29(0.01)$ & $0.24(0.01)$ \\
AGE & $0.26(0.01)$ & $0.22(0.01)$ \\
LMP & $0.18(0.01)$ & $0.19(0.01)$ \\
\hline
\end{tabular}

Source: own edition

The estimated genetic correlation coefficients among the examined traits were negligible (table 3 ). Using the dataset of the $\mathrm{Pi}, \mathrm{Ha}$ and $\mathrm{Pi} \times \mathrm{Ha}$ genotypes the estimated genetic correlation coefficient were 0.01 and -0.01 between the ADG and LMP and between the AGE and LMP, respectively. Fort he other dataset $(\mathrm{Pi}, \mathrm{Du}$ and $\mathrm{Pi} \times \mathrm{Du}$ ) these values were -0.07 and 0.04 , respectively. Similar genetic correlations were found among these traits for Hungarian Large White and Hungarian Landrace pigs (Nagy et al., 2008). On the contrary a moderate and negative genetic correlation $(-0.42)$ was estimated between the ADG and LMP by Stege et al. (2010).

Table 3.

Estimated genetic correlation coefficients among the examined traits (standard errors are given in brackets)

\begin{tabular}{lcc}
\hline & $\mathrm{Pi}, \mathrm{Ha}, \mathrm{Pi} \times \mathrm{Ha}$ & $\mathrm{Pi}, \mathrm{Du}, \mathrm{Pi} \times \mathrm{Du}$ \\
\hline $\mathrm{ADG}-\mathrm{LMP}$ & $0.01(0.04)$ & $-0.07(0.02)$ \\
$\mathrm{AGE}-\mathrm{LMP}$ & $-0.01(0.05)$ & $0.04(0.03)$ \\
\hline
\end{tabular}

Source: own edition

Based on the (BLUP) estimates of the genotype effects it could be concluded that the LMP performances of the crossed genotypes practically did not exceed that of the parental breeds. This finding was however not surprising taking into account the exceptional LMP performance of the Pietrain pigs. Justifying our results Wolf et al. (2006) reported negative heterosis for LMP examining the same genotypes as in this study. AGE and $\mathrm{ADG}$ are equivalent traits showing opposite tendencies in numerical values. The heterosis estimates were substantial for AGE (table 4).

The magnitudes of these heterosis estimates were similar to those of reported by the relevant literature. McLaren et al. (1987) examined the Duroc, Yorkshire, Landrace and Spotted breeds together with their crosses and observed $10.5 \%$ and $7.5 \%$ heterosis for ADG and AGE, respectively. Lower heterosis values 
(3.6\% and 3.2\%) were found for ADG and AGE by Lo et al (1992) evaluating Landrace $\times$ Duroc pigs. Based on the performances of Landrace $\times$ Hampshire pigs Baas et al (1992) reported a highly favourable heterosis of $11.5 \%$ for ADG.

The magnitudes of the different environmental factors influencing the examined traits are provided in table 5 .

Table 4

Magnitudes of the estimated heterosis of the examined traits

\begin{tabular}{lcrrrrc}
\hline & \multicolumn{2}{c}{ ADG } & \multicolumn{2}{c}{ AGE } & \multicolumn{2}{c}{ LMP } \\
& $\mathrm{g}$ & $\%$ & \multicolumn{1}{c}{ day } & $\%$ & $\%$ & Het. \% \\
\hline $\mathrm{Pi} \times \mathrm{Ha}$ & 36.77 & 6.76 & 11.77 & 6.74 & 0.05 & 0.08 \\
$\mathrm{Pi} \times \mathrm{Du}$ & 26.74 & 4.93 & 7.33 & 4.17 & 0.09 & 0.44 \\
\hline
\end{tabular}

Source: own edition

Table 5 .

The maximum magnitude of the environmental factors expressed as \% of the examined traits' mean

\begin{tabular}{lrcr}
\hline & AGE & LMP & ADG \\
\hline Weight & 0.37 & - & - \\
Year-month & 16.45 & 5.69 & 15.65 \\
Sex & 3.74 & 0.24 & 2.51 \\
Herd & 53.67 & 14.16 & 41.17 \\
Genotype & 7.57 & 4.45 & 8.17 \\
\hline
\end{tabular}

Source: own edition
The effects of the environmental factors were the smallest for LMP. This finding was not surprising taking into account the small standard deviation of this trait. The magnitudes of the herd effects were the largest for all traits. The effects of body weight were negligible for AGE and LMP. Vígh et al. (2007) reported similar results evaluating the field test data of the Hungarian Large White pigs. According to their results the magnitudes of the herd effects were large while the year and month effects were small for ADG.

\section{CONCLUSIONS}

Based on the results it can be concluded that crossing was relatively inefficient for LMP. On the contrary the magnitudes of the observed heterosis were not negligible for AGE and ADG. The examined traits were affected most substantially by the herd effects suggesting that there are large technological differences. The relatively low LMP heritabilities may suggest an imprecise ultrasound scanning.

\section{IRODALOM}

Baas, T. J.-Christian L. L,-Rothschild, M. F. (1992): Heterosis and recombination effects in Hampshire and Landrace swine: II. Performance and carcass traits. J. Anim. Sci. 70: 99-105.

Bühler, R.-Postler, G. (2004): Ökologischer Gesamtzuchtwert Schwäbisch-Hällisches Schwein. Forschungsprojekt 02OE396.

Csató, L.-Nagy, I.-Farkas, J.-Radnóczi, L. (2002): Genetic parameters of production traits of Hungarian Pig populations evaluated in separate and joint (field and station) tests. Arch. Tierz. 45: 375-386.

Csató, L.-Nagy, I.-Farkas, J.-Radnóczi, L.-Vígh, Zs. (2004): Examination of the genetic connectedness of Various Hungarian pig populations. Agriculturae Conspectus Scientificus. 69: 87-90.

Farkas, J. (2008): Comparative evaluation of complex BLUP models in the Hungarian pig breeding (in Hung.). PhD Thesis. Kaposvar. 191.

Geysen, D.-Janssens, S.-Vandepitte, W. (2000): $51^{\text {th }}$ Annual meeting of the European Association for Animal Production. August $21^{\text {th }}-24^{\text {th }} 2000$. The Hague. The Netherlands. Commission on Pig Production. Session P2.

Groeneveld, E. (1990): PEST Users' Manual. Institute of Animal Husbandry and Animal Behaviour Federal Research Centre. Neustadt. Germany. 1-80.

Groeneveld, E.-Kovac, M.-Mielenz, N. (2008): VCE User's Guide and Reference Manual. Version 6.0. Institute of Farm Animal Genetics. Neustadt. Germany. 1-125.

Jasek, S.-Filistowicz, M.-Korzeniowski, W. (2006): The relationship between RYR1 gene polymorphizm and reproduction performance sows of breeds: polish landrace, duroc, hampshire and pietrain. Acta fytotechnica et zootechnica - Mimoriadne číslo Nitra, Slovaca Universitas Agriculturae Nitriae. 26.

Kanis, E.-De Greef, K. H.†-Hiemstra, A.-van Arendonk, J. A. M. (2005): Breeding for societally important traits in pigs. J. Anim. Sci. 83: 948-957.
Klimas, R.-Klimienë, A. (2009): Genetic trend and relationship of meatiness traits of different breed pigs raised in Lithuania. Proceedings of the Latvian Academy of Sciences. Section B. 63. 1-2: (660-661): 66-69.

Knapp, P.-Willam, A.-Sölkner, J. (1997): Genetic parameters for lean meat content and meat quality traits in different pig breeds. Livest. Prod. Sci. 52: 69-73.

Komlósi I. (1999): A tenyészértékbecslés európai gyakorlata. A sertés. 4: 4-9.

Kövér Gy.-Csörnyei Z.-Nagy I.-Novozánszky G.-Kovács G. (2002): A testösszetétel különböző módszerekkel történő becsülhetőségének összehasonlitása sertéseken. Állattenyésztés és Takarmányozás. 51: 587-596.

Lo, L. L.-McLaren, D. G.-McKeith, F. K.-Fernando, R. L.-Novakofski, J. (1992): Genetic analyses of growth, real-time ultrasound, carcass, and pork quality traits in Duroc and Landrace pigs: I. Breed effects. J. Anim. Sci. 70: 2373-2386.

Lo, L. L.-McLaren, D. G.-McKeith, F. K-Fernando, R. L.-Novakofski, J. (1992): Genetic analyses of growth, real-time ultrasound, carcass, and pork quality traits in Duroc and Landrace pigs: II. Heritabilities and correlations. J. Anim. Sci. 70: 2387-2396.

Nagy, I.-Csató, L.-Farkas, J.-Gyovai, P.-Radnóczi, L.-Komlósi, I. (2008): Genetic parameters of direct and ratio traits from field and station tests of pigs. Arch. Tierz. 51: 172-178.

Nagy, I.-Curik, I.-Farkas, J.-Csató, L.-Csörnyei, Z. (2009): Bayesian inference of genetic parameters on litter size and gestation length in Hungarian Landrace and Hungarian Large White pigs. Ital. J. Anim. Sci. (Suppl. 3.) 8: 68-70.

McLaren, D. G.-Buchanan, D. S.-Johnson, R. K. (1987): Individual heterosis and breed effects for postweaning performance and carcass traits in four breeds of swine. J. Anim. Sci. 64: 83 . 
MGSZH (2000): Pig performance testing code 3. 1-79.

MGSZH (2009): Pig performance testing code 7. 1-73.

Radnóczi L.-Kövér Gy.-Farkas J.-Nagy I. (2009): A hazai sertésállományok genetikai potenciáljának értékelése, teljesítményvizsgálati eredményeik alapján. Állattenyésztés és takarmányozás. 58: 397-410.

Serbán B.-Csató L.-Farkas J. (2000): A magyarországi sertés üzemi sajátteljesítmény-vizsgálat elemzése genetikai paraméterek alapján. Acta Agraria Kaposváriensis. 4: 9-22.

Stamer, E.-Brade, W.-Kalm, E. (2007): Genetische Beziehungen zwischen Reinzucht- und Kreuzungsleistungen sowie verschiedenen Prüfumwelten beim Schwein, untersucht am Material niedersächsischer Prüfstationen. Züchtungskunde. 79: 298-308.

Stamer, E.-Brade, W.-Kalm, E. (2008): Genetische Trends in der Niedersächsischen Piétrain-Eberpopulation in Abhängigkeit vom MHS-Status. Züchtungskunde. 80: 265-278.
Stege, H.--Jensen, T. B.-Bagger, J.-Keller, F.-Nielsen, J. P.-Ersbøll, A. K. (2010): Association between lean meat percentage and average daily weight gain in Danish slaughter pigs. Preventive Veterinary Medicine. doi:10.1016/j.prevetmed.2010.12.003

Szőke Sz.-Komlósi I. (2000): BLUP modellek összehasonlítása. Állattenyésztés és Takarmányozás. 49: 231-245.

Váradi G.-Bartos A.-Pozsgai É. (1997): A magyar nagyfehér hússertés és a duroc sertés néhány jelentősebb kvantitatív tulajdonsága. Állattenyésztés és Takarmányozás. 46: 227-236.

Vígh Zs.-Csató L.-Gyovai P.-Nagy I. (2007): Környezeti nagyságok hatása a magyar nagyfehér hússertés üzemi sajátteljesítmény vizsgálatában. Agro Napló. 11. 5: 85-86.

Wolf, J.-Peskovicova, D.-Zakova, E.-Groeneveld. E. (2006): Additive and heterotic breed effects in the genetic evaluation of pig sire breeds. Anim. Sci. 82: 455-462.

Youssao, I.-Verleyen, V.-Michaux, C.-Leroy, P. L. (2002): Choice of probing site for estimation of carcass lean percentage in Piétrain pig using the real-time ultrasound. Biotechnol. Agron. Soc. Environ. 6: 195-200. 